\title{
THE EFFECT OF SUPPLY AUTOMATION SYSTEMS TECHNICAL OPERATIONS READINESS OF INDONESIAN WARSHIP (CASE STUDY: DOPUSBEKTIM)
}

\author{
Antonius Fandiano \\ Indonesian Naval Command and Staff School, \\ Seskoal Cipulir, Jakarta 12230, Indonesia
}

\begin{abstract}
In the system of guiding material for the Navy the spare parts are supporting material because of their nature as a provision that supports the maintenance of the main material so that it is always maintained and maintained its quality. The Eastern Region Procurement Center Depot or Dopusbektim is the Technical Implementation Unit (UPT) of Head quarter of Indonesian Navy Service, which has the duty and responsibility to receive, store, maintain and distribute provisions to the user unit or user unit including of Indonesian Warship In especially those located in the Koarmatim region or currently is Second Fleet of Indonesian Navy (Koarmada II). In supporting its duties and functions as a storage and distribution facility, Dopusbektim has a structured and implemented supply pattern supported by an automated system that uses special applications so that the distribution process can be carried out better in supporting technical operations readiness of Indonesian Warship. However, in carrying out the Dopusbektim debriefing, it was felt that it was not optimal although it was supported by infrastructure because there were still obstacles and obstacles. This results in Dopusbektim's duties and functions, one of which is providing services in order to support technical operations readiness of Indonesian Warship has not been maximized. Therefore it is necessary to analyze which effects need to be improved in optimally supporting technical operations readiness of Indonesian Warship .
\end{abstract}

Keywords: Supplies Pattern, Automation System, Indonesian Warship Technical Operational Readiness, Multiple Regression analysis.

\section{INTRODUCTION}

There are six main elements that are a condition for a country to control the ocean in the maritime perspective contained in the theory of Sea Power. One manifestation of the character of the government that supports the theory is the development of defense forces at sea which certainly has the ability to overcome all forms of threats that exist or come from the sea with the Navy as the main component of defense forces at sea. Indonesian Warship as the spearhead of the Navy element which is an implementation of the presence of the state at sea must always be ready to be able to respond and move quickly to any situation and condition so that there is a demand for operational readiness.

With the condition of the ship that is always ready for operation, it is hoped that all Indonesian Warships will be able to become elements of a force that is ready to fight when the state is in an emergency. The Navy Organization from the beginning has determined the system or procedure governing the logistics or stock support mechanism including the initial provision of Indonesian Warship spare parts to ensure operational readiness and durability while in the sea or operational area.

Eastern Region Procurement Center Depot or Dopusbektim is the Technical Implementation Unit (UPT) of Mabesal under the Armed Forces of the
Navy Navy Service who has the duty and responsibility to receive, store, maintain and distribute provisions to user units or user units including Indonesian Warship especially those located in the Koarmatim area or this time is Second Fleet Of Indonesian Navy.

In supporting its duties and functions as a storage and distribution facility, Dopusbektim has a structured and implemented supply pattern supported by an automated system that uses special applications so that the distribution process can be carried out better in supporting technical operations readiness of Indonesian Warship .

\section{MATERIALS AND METHODS}

\subsection{System Theory}

In everyday life we often hear the word system, especially in the military or defense. This system varies from a military organization system, a weapons system to a military education system and many other systems. The word system itself comes from Latin namely sistema and Greek sustema which means a unity consisting of several subsystems connected to achieve a goal.

According to Jogiyanto the system is a combination of various elements that are related and interact to accomplish certain goals by describing the events and the unity of real objects. For example humans, objects or places. Some 
elements or components that make up a system so that the system generates valid reports consist of:

a. The object. This object can be physical or abstract or both.

b. Attributes, namely the characteristics of objects that are components that make up the system.

c. Internal relationships, are the links between objects that are in a system.

d. Environment, is the place or location where the system is located or used.

e. Purpose, is the goal or purpose to be achieved in the system used.

f. Input, something in the form of information entered into the system which is then processed to produce output.

g. Process, a part or component of a system that converts inputs into outputs.

h. Output, is the result of input that has been processed can be in the form of reports, information or data.

\subsection{Otomation Theory}

Automation is a job that uses technology by combining the application of mechanical science, electronics and computer-based systems through processes or procedures that are prepared based on the instruction program and combined with automatic control (catubalik) to ensure whether all instructions have been carried out completely correctly so that productivity, efficiency and increased flexibility.

Basically the instruction in question is work carried out by humans but due to technological developments the instruction is packaged in a computer program that can run on its own without using human labor. This is of course very useful because it can increase productivity with the existence of time and energy efficiency.

\subsection{Military logistic Theory}

In a military operation or in a tactic warfare, strategy and logistics are inseparable parts of one another. Tactics and strategies function how the military or war operation runs while the logistics function to support the needs during the military or war operation to take place so that the intended activity is carried out in accordance with the objectives to be achieved. Planning for logistical support needs is closely related to the tactics and strategies used because it is related to the amount of power used and the length of the operation that was held. Thus military logistics can be interpreted as the science of planning and budgeting movements and maintaining a military force.

In military organizations have a logistical system to support military activities themselves, namely:

a. Defense Logistics. It is a policy in planning, organizing, implementing, controlling and controlling logistics in accordance with the logistical support mechanism that has been arranged so that the logistics are ready for use by the user unit.

b. Regional Logistics. Is a place used to store logistics can be in the form of buildings or warehouses placed in areas that become the defense and resistance areas.

\subsection{Readiness Theory}

Readiness is a condition that makes or causes a response and reaction to a situation that will or is being faced. From this information it can be interpreted that of Indonesian Warship In readiness is a condition where of Indonesian Warship In is technically and the entire system in it can function as it should and is then ready to carry out operations both military operations and non military operations.

\subsection{Definition of Multiple Regression analysis.}

Regression Analysis is used by researchers in order to find out how much influence the value of the dependent variable if the value of the independent variable is changed (Sugiyono, 2004: 206). Regression is useful for analyzing between one with another variable conceptually having a causal relationship.

$Y=a+b X$

Value and can be obtained using the formula:

$$
\begin{aligned}
& a=\frac{(Y)(X 21)(X 1)(X 1 Y)}{n \times 21-(x 1)^{2}} \\
& b=\frac{n(X 1 Y)-(X 1)(Y)}{n \times 21-(x 1)^{2}}
\end{aligned}
$$

Where :

$\mathrm{Y}=$ Subject / Value in the predicted dependent variable

$\mathrm{a}=$ Price of $\mathrm{Y}$ if $\mathrm{X}=0$ (constant price)

$\mathrm{b}=$ Number of direction or coefficient of regression, which shows the number of increase or decrease in the dependent variable based on the independent variable. If $b(+)$ there will be an increase, and if (-) there will be a decrease.

$X=$ Subject to the independent variable that has a certain value.

Conditions:

If $b=0$, then the independent variable does not affect the dependent variable.

If $b>0$, then the independent variable does not affect the dependent variable.

If $b>0$, then the independent variable has a negative effect on the dependent variable.

Furthermore, the results of calculating the correlation between variables from the Regression analysis can be guided by the table below: 
Table 1. Guidelines for giving Interpretation of the Correlation Coefficient

\begin{tabular}{|c|c|}
\hline Internal & $\begin{array}{c}\text { Coefficient of } \\
\text { Relationship Level }\end{array}$ \\
\hline $0.00-0.1999$ & Very low \\
\hline $0.20-0.3999$ & Low \\
\hline $0.40-0.5999$ & Medium \\
\hline $0.60-0.7999$ & Strong \\
\hline $0.80-1.0000$ & Very Strong \\
\hline
\end{tabular}

Source: Sugiyono (2004: 183)

To find out if it is true that the independent variable has a relationship with the dependent variable, it can be done using a t test with a significant level of $5 \%$, then the results of the test are compared with the table. If $t$ arithmetic is smaller than or equal to the table then the variable $X$ does not have a relationship with the variable $Y$ while if $t$ arithmetic is greater than $t$ then the variable $X$ has a relationship with the variable $Y$.

Pict 1. Flowchart of Regression Analysis

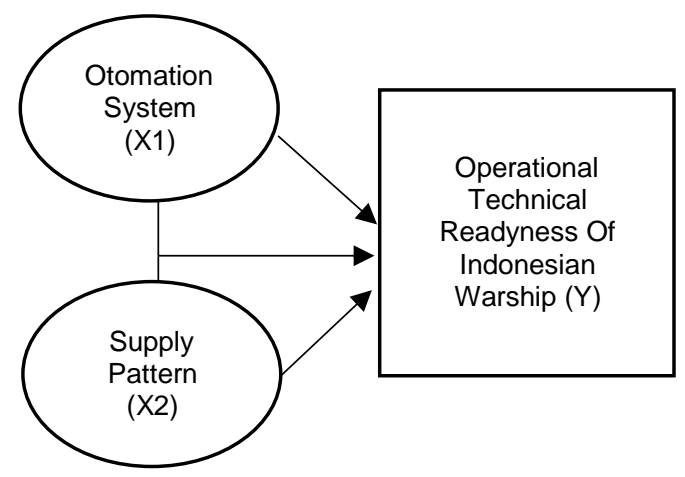

\section{RESULTS AND DISCUSSION.}

The method used in this research is quantitative method. Quantitative Method is a research method that is based on the philosophy of positivism, which is used to conduct research on a particular population or sample, data collection using research instruments, quantitative / statistical data analysis, which has the aim to test a predetermined hypothesis.

\subsection{Data Collection Techniques.}

The data collection techniques used by researchers in this study are as follows:

a. $\quad$ Field Research (field work research).

Namely direct data collection which is the object of research to look closely at the company, using the method:

1) Observation (observation)

2) Interview (interview)

3) Questionnaire b. Library Research (library research).

The secondary data was obtained through data that has been recorded, both in the form of reports and the results of previous research.

\subsection{Result.}

The validity test is carried out first on the Questionnaire that is distributed to the personnel in Dopusbektim to find out whether the instruments arranged are truly capable of measuring what is desired. Validity test itself is used to measure how valid an instrument can reveal the data of the variable being studied appropriately. The results of the validity test can be seen through the answers in table 2 below

Table 2. Validation for Automation System Variables.

\begin{tabular}{|c|c|c|c|}
\hline \multicolumn{4}{|c|}{ Otomation System } \\
\hline Question & R Result & R Table & Validation \\
\hline 1 & 0.744 & 0.361 & VALID \\
\hline 2 & 0.875 & 0.361 & VALID \\
\hline 3 & 0.804 & 0.361 & VALID \\
\hline 4 & 0.697 & 0.361 & VALID \\
\hline
\end{tabular}

Table 3. Validation for Supply Pattern Variables.

\begin{tabular}{|c|c|c|c|}
\hline \multicolumn{4}{|c|}{ DOPUSBEKTIM Suppy Pattern } \\
\hline Question & R Result & R Table & Validation \\
\hline 1 & 0.549 & 0.361 & VALID \\
\hline 2 & 0.416 & 0.361 & VALID \\
\hline 3 & 0.697 & 0.361 & VALID \\
\hline 4 & 0.562 & 0.361 & VALID \\
\hline 5 & 0.411 & 0.361 & VALID \\
\hline 6 & 0.334 & 0.361 & \\
\hline 7 & 0.402 & 0.361 & VALID \\
\hline 8 & 0.816 & 0.361 & VALID \\
\hline 9 & 0.705 & 0.361 & VALID \\
\hline 10 & 0.118 & 0.361 & \\
\hline 11 & 0.533 & 0.361 & VALID \\
\hline 12 & 0.353 & 0.361 & \\
\hline 13 & 0.696 & 0.361 & VALID \\
\hline 14 & 0.633 & 0.361 & VALID \\
\hline 15 & 0.142 & 0.361 & \\
\hline
\end{tabular}

Table 4. Validation for Operational Technical Readiness Variables Indonesian Warship Second Fleet Of Indonesian Navy

\begin{tabular}{|c|r|r|l|}
\hline \multicolumn{4}{|c|}{$\begin{array}{l}\text { Operational Technical Readiness of } \\
\text { Indonesian Warship in Koarmada II }\end{array}$} \\
\hline Question & R Result & R Table & Validation \\
\hline 1 & 0.391628165 & 0.361 & VALID \\
\hline 2 & 0.692637216 & 0.361 & VALID \\
\hline 3 & 0.823446886 & 0.361 & VALID \\
\hline 4 & 0.791942131 & 0.361 & VALID \\
\hline 5 & 0.692637216 & 0.361 & VALID \\
\hline 6 & 0.70870483 & 0.361 & VALID \\
\hline 7 & 0.70870483 & 0.361 & VALID \\
\hline 8 & 0.791942131 & 0.361 & VALID \\
\hline 9 & 0.461903842 & 0.361 & VALID \\
\hline 10 & 0.435108876 & 0.361 & VALID \\
\hline
\end{tabular}


From the results of the above table it can be explained that the questionnaire / questionnaire instrument against the respondent is declared valid if the value of $r$ count is greater than the table value, so based on these requirements, the items in the questionnaire / lift related to the Automation System Variable (X1) are declared fully valid. While the items in the questionnaire / lift related to the Dopus Supply Pattern variable (X2) were declared valid only 11 questions while 4 questions namely items 6 . 10. 12 and 15 must be excluded from the existing question instrument. Then the items in the questionnaire / lift related to the variable Operational Technical Readiness of Indonesian Warship Second Fleet Of Indonesian Navy (Y) are declared to be fully valid.

After Validation is performed, then the reliability test is performed to determine whether the data collection tool basically shows the level of accuracy, accuracy, stability or consistency. Reliable instruments are instruments that, if used several times to measure the same object, will produce the same data. A good instrument will not be tendentious in directing respondents to choose certain answers. (Suharsimi Arikunto, 2006: 178). Priyatno said that "A construct or instrument variable is said to be reliable, if it gives a Cronbach's Alpha coefficient value greater than 0.6 (as a general standard value for accepting the reliability of a research instrument). In general, the reliability of a research instrument in the range> 0.60 to 0.80 can be said to be good, if in the range> 0.80 to 1.00 is considered very good ". Then the reliability test results can be seen in table 2 as follows:

Table 5.Realibility test

\begin{tabular}{|c|c|c|}
\hline \multicolumn{2}{|c|}{ Variable } & $\begin{array}{c}\text { Alpha Cronbach's } \\
\text { Value }\end{array}$ \\
\hline X1 & Otomation System & 0.78219 \\
\hline X2 & DOPUSBEKTIM Suppy Pattern & 0.82730 \\
\hline Y & $\begin{array}{c}\text { Operational Technical Readiness of } \\
\text { Indonesian Warship in Koarmada II }\end{array}$ & 0.84941 \\
\hline
\end{tabular}

By looking at the results of the Reliability Test value in the table above, it can be concluded that the Cronbach Alpha Value obtained from the three variables used are Automation System variables, Dopus Supply Pattern variable and Indonesian Warship Operational Technical Readiness respectively are $0.782,0.827$, and 0.849 . Then the value gives an indication that the reliability of the questionnaire / questionnaire used as a measurement is included in the category of strong correlations for each variable. This reliability test gives an indication that the reliability of the questionnaire / questionnaire used as a gauge for all three variables is included in the high category and is accepted. Because each alpha value exceeds the cut-off value of 0.6 , all items can be said to be reliable
After the questionnaire has been validated and the reliability test is done then the classic assumption test is needed so that the results of the analysis with multiple regression methods can be done. The classic assumption test consists of several tests, namely the normality test, the heteroscedaticity test, and the multicollinearity test. The normality test is a test of normality of data distribution, which can be seen through the image of the histogram curve and the $p-p$ curve plot to show the distribution of research data. Normal data will be seen to spread to all areas of the normal curve, while data that are not normally distributed will be on the left and right side of the normal curve line. (Hastono, 2007: 85).

Picture 2. Normality test

Normal P.P Plot of Rearession Standardized Residual Dependent Variable: Technical Operation Readiness of Indonesian Warship in Koarmada II

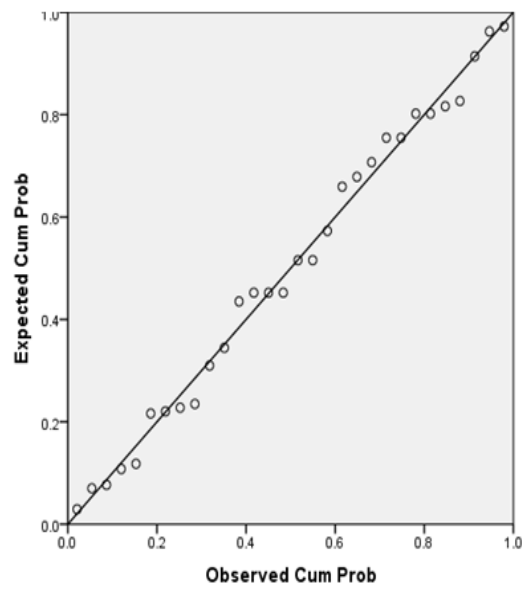

From the above plot pattern it can be seen that the data distribution is around the curve line without a single point at a very far position, with conditions like this it can be said that the data has a normal distribution so that multiple regression analysis can be done other than that to strengthen the results of the line pattern The normality test was also carried out using the Kolmogorov Smirnov test with the following results:

Table 6. Kolmogorov normality test One-Sample Kolmogorov-Smirnov Test

\begin{tabular}{|ll|r|r|r|}
\hline & & $\begin{array}{c}\text { Technical } \\
\text { Operation } \\
\text { readiness of }\end{array}$ & Supply Pattern & $\begin{array}{c}\text { Otomation } \\
\text { System }\end{array}$ \\
& & $\begin{array}{c}\text { Indonesian } \\
\text { Warship In } \\
\text { Koarmada II }\end{array}$ & & \\
\hline $\mathrm{N}$ & & 30 & & \\
Normal Parameters & & 34.2667 & 37.7333 & 13.8333 \\
& Mean & 5.05783 & 4.96841 & 2.43655 \\
& Std. Deviation & .133 & .112 & .141 \\
Most Extreme Differences & Absolute & .133 & .112 & .141 \\
& Positive & -.075 & -.062 & -.089 \\
Kolmogorov-Smirnov Z & Negative & .726 & .613 & .771 \\
Asymp. Sig. (2-tailed) & & .667 & .847 & .592 \\
\hline
\end{tabular}

a. Test distribution is Normal.

b. Calculated from data. 
From the Kolmogorov-Smirnov test results it can be seen that the three variables meet the normality assumption because the value obtained by Kolmogorov Smirnov has a value greater than 0.05 .

Heteroskedsticity test aims to test whether in the regression model there is an inequality residual variance from one observation to another observation. If the variance from one observation residual to another is not fixed, then a heteroscedsticity problem is suspected. Heteroskedsticity occurs due to changes in the situation that are not described in the regression model specifications, in other words heteroskedsticity can be known by looking at the distribution and variance of residuals in scatter diagrams or thick diagrams (scatter-plot). The Xaxis in the scatter diagram usually shows the independent variable, while the $Y$ axis shows the dependent variable.

After the Normality Test is carried out, the Heteroskedsticity test is then performed which aims to test whether in the regression model there is an inequality residual variance from one observation to another. If the variance from one observation residual to another is not fixed, then a heteroscedsticity problem is suspected.

Heteroscedaticity itself occurs due to changes in the situation that are not described in the regression model specifications, in other words heteroscedaticity can be known by looking at the distribution and variance of residuals in scatter diagrams or thick diagrams (scatter-plot). The Xaxis in the scatter diagram usually shows the independent variable, while the $Y$ axis shows the dependent variable.

Picture 3. Heteroscedasticity test

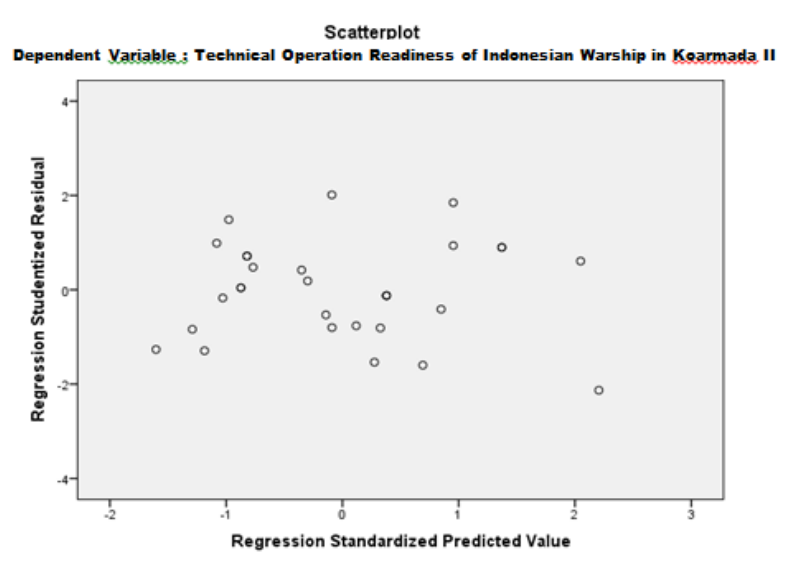

From the scatterplot graph above it can be assumed that there are no clear patterns, and the points spread above and below zero on the $Y$ axis, then there is no heteroscedasticity.

Furthermore, after the heteroscedasticity test. The multicollinearity test is performed, where the multicollinearity test is one of the classic assumptions tests used to test whether the regression model found a correlation between independent variables. If there is a correlation, then there is a problem called multicollinearity (Ghozali, 2005). Where the results of the multicollinearity test can be seen in the table below:

Table 7. Table VIF values of each variable Coefficients $^{\mathrm{a}}$

\begin{tabular}{|ll|r|r|}
\hline \multirow{2}{*}{ Model } & \multicolumn{2}{|c|}{ Collinearity Statistics } \\
\cline { 3 - 4 } & \multicolumn{1}{|c|}{ Tolerance } & \multicolumn{1}{c|}{ VIF } \\
\hline \multirow{2}{*}{1} & (Constant) & & \\
& Otomation System & .212 & 4.720 \\
& Supply Pattern & .212 & 4.720 \\
\hline
\end{tabular}

Multicollinearity can be seen from (1) tolerance value and its opponents (2) Variance Inflation Factor (VIF), these two measures indicate which each independent variable is explained by other independent variables. Tolerance measures the variability of selected independent variables that are not explained by other independent variables. So, a low tolerance value is the same as a high VIF value (because VIF $=1 /$ Tolerance). The cut-off value commonly used to indicate multicollinearity is a tolerance value $<0.10$ or equal to a VIF value $>10$ (Ghozali, 2005). Then from table 7 it can be concluded that all variables are free from the model free from multicollinearity symptoms.

The results of data processing with multiple regression analysis obtained the following results:

a. Partial Test ( $t$ test)

The results of the $t$ test in this study can be seen in the following table:

Table 8. T test

\begin{tabular}{|c|c|c|c|c|c|c|}
\hline \multicolumn{7}{|c|}{ Coefficients $^{\mathrm{a}}$} \\
\hline \multirow[t]{2}{*}{ Mod } & & \multicolumn{2}{|c|}{ Unstandardized Coefficients } & \multirow{2}{*}{$\begin{array}{c}\text { Standardized } \\
\text { Coefficients } \\
\text { Beta } \\
\end{array}$} & \multirow[t]{2}{*}{$t$} & \multirow[t]{2}{*}{ Sig. } \\
\hline & & B & Std. Error & & & \\
\hline \multirow{3}{*}{1} & (Constant) & 3.161 & 1.693 & & 1.867 & .073 \\
\hline & Otomation System & 1.544 & .189 & .744 & 8.184 & .000 \\
\hline & Supply Pattern & .258 & .093 & .254 & 2.792 & .010 \\
\hline
\end{tabular}

From the table above $T$ test results by looking at the significance value of the Automation System variable has a significance value smaller than the Alpha value of 0.05 , so it can be concluded that the automation variable has a significant influence on the Technical Readiness of Indonesian Warship Operations in Koamada II

\section{b. Variables $(\mathrm{X} 2)$}

From the table of $T$ test results above by looking at the significance value of the Dopusbektim Debriefing Pattern variable, the significance value is smaller than the Alpha value of $0.05,0.01$, so it can also be concluded that the Dopusbektim Debriefing Pattern variable has a significant effect on 
Indonesian Warship Operational Technical Readiness at Second Fleet Of Indonesian Navy.

\section{c. Simultaneous Test (F Test)}

Table 9. $\mathrm{F}$ test

\begin{tabular}{|c|c|c|c|c|c|c|}
\hline \multicolumn{7}{|c|}{ ANOVA $^{a}$} \\
\hline Model & & Sum of Squares & $d f$ & Mean Square & $\mathrm{F}$ & Sig. \\
\hline \multirow{3}{*}{1} & Regression & 706.811 & 2 & 353.405 & 272.193 & $.000^{\mathrm{b}}$ \\
\hline & Residual & 35.056 & 27 & 1.298 & & \\
\hline & Total & 741.867 & 29 & & & \\
\hline
\end{tabular}

a. Dependent Variable: Technical operation readiness of Indonesian Warship in Koarmada II b. Predictors: (Constant), Supply Pattern, Otomation System

From the $\mathrm{F}$ test results in the above table, the calculated $F$ value is obtained with a value of 272,193 . This means that the value of $F$ arithmetic is greater than $\mathrm{F}$ table 9 . the degree of freedom 1 used is 5 and the degree of freedom 2 is 26 , and by looking at the significance value obtained is smaller than the alpha value of 0.05 . So on the basis of the two comparisons, it can be concluded that the two independent variables possess a significant or simultaneous influence on the independent variable so that it can be said that the model used is appropriate.

\section{d. Determination Test}

While how much influence the variable Automation System (X1) and Supplies Pattern (in explaining the variable Indonesian Warship Technical Readiness in Fleet II, can be seen in the table below.

Table 10. Calculation Results for the Determination Coefficient of Variable $X$ with $Y$

Model Summary ${ }^{b}$

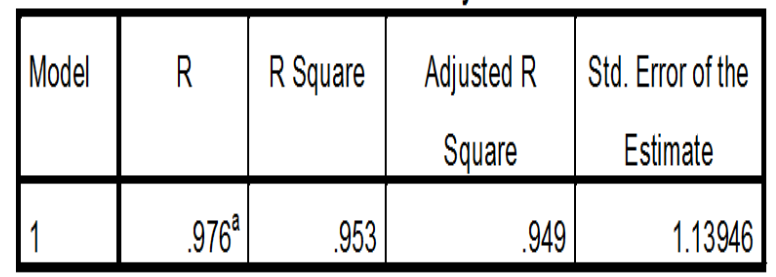

By looking at the coefficient of determination in the table above can be obtained how much influence the variable Automation System (X1) and Dopusbektim Supply Pattern (X2) in explaining the variable Technical Readiness of Indonesian Warship Operations in Second Fleet Of Indonesian Navy ( $Y$ ). From the value of $R$ in the table above states that the relationship between independent variables in influencing the dependent variable $(Y)$ is quite strong, which is equal to 0.976 . While the coefficient of determination shown in the value of RSquare or equal to 0.953 indicates that the ability of the Automation System variable (X1) and the Dopusbektim Supply Pattern (X2) in explaining of
Indonesian Warship In Operational Technical Readiness variable in Second Fleet Of Indonesian Navy $(Y)$. is $95.3 \%$, while the remaining $4.7 \%$ is influenced by other variables not included in the model.

Because of the results both partially and simultaneously obtained that the independent variables have a significant effect so that the regression model used by using the coefficient of determination is as follows:

Regression line equation $=$

$\mathrm{Y}=0.744 \mathrm{X} 1+0.254 \mathrm{X} 2$

By using a regression equation with a coefficient of determination, it can be concluded that the model obtained can only be used in the current conditions so that it cannot be used as a model for predicting conditions in the future. This happens because the conditions in the field can change due to the change of personnel in the highly dynamic environment of Second Fleet Of Indonesian Navy.

The automation system and the Dopusbektim Supply Pattern can be said to have a partial effect on of Indonesian Warship In Operational Technical Readiness. Can be seen through the basic hypothesis below:

H0: Partial Automation System and Procurement Pattern in Dopusbektim has no effect on the Technical Readiness of Indonesian Warship Operations in Second Fleet Of Indonesian Navy.

H1: Automation System and Procurement Pattern in Dopusbektim Partially affect the Technical Readiness of Indonesian Warship Operations in Second Fleet Of Indonesian Navy

So from the results of data processing by looking at the $T$ test which is a partial test of influence between the independent variables on the dependent variable, the significance value obtained is smaller than the alpha value of 0.05 then $\mathrm{Ho}$ is rejected and $\mathrm{H} \mathrm{I}$ is accepted so it can be concluded that partially the Automation System and the Provisioning Pattern Dopusbektim partially has an influence in explaining of Indonesian Warship In Operational Technical Readiness variable in Second Fleet Of Indonesian Navy.

While the Automation System and Pattern of Dopusbektim Supply are said to be simultaneously (simultaneously) influencing the Technical Readiness of Indonesian Warship Operations in Second Fleet Of Indonesian Navy. Viewed on the basis of the hypothesis below:

HO: Automation System and Pattern of

Procurement in Dopusbektim together (simultaneously) does not affect the Technical Readiness of Indonesian Warship Operations in Second Fleet of Indonesian Navy. 
$\mathrm{H} 1$ : Automation System and Pattern of Supply in Dopusbektim together (simultaneously) affect the Technical Readiness of Indonesian Warship Operations in Second Fleet of Indonesian Navy.

So from the results of data processing by looking at the $F$ test which is a test of influence simultaneously between the three independent variables on the dependent variable, the significance value obtained is smaller than the alpha value of 0.05 , then $\mathrm{Ho}_{\mathrm{o}}$ is rejected and $\mathrm{HI}_{\mathrm{I}}$ is accepted so that it can be concluded that the variable Automation System simultaneously and The Dopusbektim Supplies pattern simultaneously (simultaneously) has an influence in explaining of Indonesian Warship In Operational Technical Readiness variable in Second Fleet Of Indonesian Navy.

From the results of the above processing, it is found that there is a real influence of the Automation System on the Technical Readiness of Indonesian Warship Operations in Second Fleet Of Indonesian Navy. This has been proven through the $T$ test which is a partial test of variable influence, thus it can be interpreted that the magnitude of the influence of the Automation System on the Technical Readiness of Indonesian Warship Operations in Second Fleet Of Indonesian Navy by looking at the value of the standardized coefficient (Standardized Coefficient) of 0.744 so that each increase in one Automation System variable will increase the Technical Readiness of Indonesian Warship Second Fleet of Indonesian Navy Operations by 0.744 .

While the results of the processing are obtained that there is a real influence of the Dopusbektim Supply Pattern on of Indonesian Warship In Operational Technical Readiness of Indonesian Warship Second Fleet Of Indonesian Navy, this has been proven through the $T$ test which is a partial test of variable influence, thus it can be interpreted that the magnitude of the influence of the Dopusbektim Procurement Pattern on of Indonesian Warship In Operational Technical Readiness of this Indonesian Warship Second Fleet Of Indonesian Navy by looking at the value of the standardized coefficient (Standardized Coefficient) is 0.254 so that each increase of one variable Dopusbektim Supply Pattern will increase the Technical Readiness of Indonesian Warship Second Fleet Of Indonesian Navy Operations by 0.254 .

\section{CONCLUSION}

By looking at each of the variables partially the research seems clear for the Automation System variable has a greater influence value than the variable Supply Mechanism in influencing the Technical Operations Readiness of of Indonesian Warship In Second Fleet Of Indonesian Navy but this automation system variable still cannot stand alone because in the model both variables have an influence on of Indonesian Warship In Operational Technical Readiness at Second Fleet Of Indonesian Navy.

The Dopusbektim Briefing Pattern Variable explains how the current work system has a significant influence on the Technical Readiness of Indonesian Warship Operations in Second Fleet Of Indonesian Navy. One can say that both organization and personnel have been running well in supporting of Indonesian Warship In Operational Technical Readiness in Second Fleet Of Indonesian Navy.

The conclusion from the discussion above can be seen that the independent variables used are Automation System and Dopusbektim Supply Patterns simultaneously (simultaneously) and partially have an influence in explaining the Technical Readiness variable of Indonesian Warship Operations in Second Fleet Of Indonesian Navy. So it is clear that the Automation System and Patching Pattern need to be implemented continuously, so that by taking into account these variables, of Indonesian Warship In Operational Technical Readiness can be carried out properly.

\section{REFERENCES}

Sugiyono (2004), Business Research Methods, CV. Alfabeta, Bandung

AT. Mahan ,. 1960-1783, The Influence of Sea Power Upon History, Twelfth Edition, Boston, Little Brown and Company, p. 82

http://etheses.uin-malang.ac.id/648/6/10410 027\% 20Chapter\% 202.pdf

http://ledhyane.lecture.ub.ac.id/files/2012/11/Testin g_Hipothesis.pdf

http://logistik-militer.civil.web.id/ind/1000884/Logistik-militer_97611_stikimalang_logistik-militer-civil.html

http://repository.upi.edu/6035/47/D3_TE_1002315_ Chapter1.pdf

https://www.academia.edu/7534109/Understanding System_According to Jogiyanto_H

Ken Booth, Navies and Foreign Policy (London: Routledge, 1977), p. 16

Priyanto Duwi, (Jakarta, 2018). SPSS Easy Guide to Data Processing for Students and the Public

Ridwan. (Jakarta, 2010). Methods and Techniques of Arranging Thesis. 